\title{
RESPONSE OF SOIL ORGANIC CARBON AND TOTAL NITROGEN STOCKS TO DESERTIFICATION OF CHINA AGRO- PASTORAL TRANSITIONAL ZONE: A STUDY OF THE SOUTHEASTERN EDGE OF THE MU US SANDY LAND
}

\author{
YANG, M. H. ${ }^{1 *}-$ MA, Z. Z. ${ }^{1}-$ ZHANG, M. C. ${ }^{1}$ \\ College of Geomatics, Xi'an University of Science and Technology, 58 Yanta Road, Xi'an, \\ Shaanxi, P. R. China \\ *Corresponding author \\ e-mail: ymh8307024@163.com; phone: +86-29-8365-3727; fax: +86-29-8558-3176
}

(Received $14^{\text {th }}$ Nov 2019; accepted $12^{\text {th }}$ Feb 2020)

\begin{abstract}
Desertification, as one of the most severe socio-economic, environmental and ecological problems, has attracted widespread attention. In this study, the severity of desertification in the southeastern edge of the Mu Us sandy land of China was classified into five stages using the space-fortime method. A field experiment was conducted in July 2015 to investigate the dynamics of soil organic carbon (SOC) and total nitrogen (TN) concentrations and stocks. The results show that SOC and TN concentrations and stocks decreased significantly with the severity of desertification, reducing SOC and $\mathrm{TN}$ concentrations by $55.5 \%$ and $55.1 \%$ in $0-30 \mathrm{~cm}$ depth, SOC and TN stocks decreasing by $54.4 \%$ and $54.0 \%$, respectively. The losses of SOC and TN stocks indicate that the impacts of desertification were more evident in upper soil, because the losses in them were higher than those in other layers, and early stages are vital to the restoration of desertification for more losses of SOC and TN stocks. SOC $\left(4.25 \times 10^{8} \mathrm{~kg}\right)$ and TN $\left(0.71 \times 10^{8} \mathrm{~kg}\right)$ accumulated from 2003 to 2015 indicate that desertification was reversed. Overall, key stages of combating desertification were identified, and the feasibility of integrating field experiment data and temporal-spatial data to evaluate the dynamics of desertification was verified.
\end{abstract}

Keywords: soil property, desertification assessment, integrated method, desertification reverse, ecological restoration

\section{Introduction}

During the past decades, carbon $(\mathrm{C})$ and nitrogen $(\mathrm{N})$ stocks in terrestrial ecosystems have attracted significant attention worldwide because of the enormous effect of $\mathrm{C}$ and $\mathrm{N}$ levels on the environment and human life (Agren et al., 1987; Deng et al., 2016; Jenkinson et al., 1977; Kelly et al., 1996). Soil, as the largest organic carbon pool in terrestrial ecosystems, plays a significant role in the soil carbon sequestration and global $\mathrm{C}$ cycle, and has intimate connections with atmospheric $\mathrm{CO}_{2}$, for it could act as its source or sink (Dessie et al., 2017; Detwiler, 1986; Post et al., 1982). According to statistics proposed by Batjes and Emanuel, soil stores about $1500 \mathrm{Pg}$ organic carbon in the top one meter, which is about 2.1 times the amount of organic carbon stored in the atmosphere and 2.7 times that in terrestrial plant biomass (Batjes, 1996; Emanuel et al., 1984). Soil also significantly affects $\mathrm{N}$ recycling, with values of $92-117 \mathrm{Pg}$ to a depth of one meter, as a comparison the vegetation biomass held $10 \mathrm{Pg}$ of $\mathrm{N}$ and microbial biomass holds about 2 Pg N (Batjes, 1996; Mehari et al., 2016; Wang et al., 2006). As key indicators for assessing soil quality and ecosystem productivity, the roles of soil organic carbon (SOC) and total nitrogen (TN) were recognized more than a century ago (Spycher et al., 1983; Twongyirwe et al., 2013). SOC and TN stocks in the soil vary as a result of climate change, land use changes, and even vegetation disturbances or 
succession (Alireza et al., 2017; Bouwman, 1990; Van Minnen et al., 2009). Therefore, understanding changes in SOC and TN stocks also plays a role of significance in determining regional, national, and even international carbon and nitrogen budgets.

Desertification is one of the most severe socio-economic, environmental, and ecological threats to the world, especially in arid, semi-arid, and dry subhumid areas (Carr et al., 1996; UNCCD, 1994). Desertification is estimated to affect $20 \%$ of the world's population and 25\% of the world's land surface (Binns, 2000; UNCCD, 1994). As an extreme case of soil degradation, variation in the amounts of SOC and $\mathrm{N}$ stocks concerning desertification caused much concern in recent years ( $\mathrm{Hu}$ et al., 2017; Tang et al., 2015; Zhao et al., 2009). Published studies have confirmed that desertification leads to a noticeable decline in SOC and N (Aweke et al., 2015; Huang et al., 2007; Zhou et al., 2008), which not only cause depletion of natural resource and losses of ecosystem services, but also enhance emissions of $\mathrm{CO}_{2}, \mathrm{NO}_{\mathrm{x}}$, and other greenhouse gases to the atmosphere (Kirschbaum, 2000; Russell et al., 2005). Zhao et al. (2009) estimated SOC and $\mathrm{N}$ contents in the desertification process in Inner Mongolia (Zhao et al., 2009). Tang et al. (2015) analyzed changes in $\mathrm{C}$ and $\mathrm{N}$ concentrations and stocks in the desert steppe ecosystem in Ningxia (Qiu et al., 2012). However, there have been only few studies on changes in SOC and TN stocks in the Agro-pastoral transitional zone. The Mu Us sandy land is one of the four largest sandy lands in China. The southeast edge of the Mu Us sandy land in Shaanxi province of Chian is of particular concern as it is a typical Agro-pastoral ecotone and semi-arid grassland area of China (Li et al., 2017).

In the past two decades, numerous studies focus on the temporal and spatial monitoring and evaluating of the desertification process with the wide application of GIS and RS (Lamchin et al., 2016; Zhang et al., 2018). These researches could directly display desertification changes based on the dynamic area data of different desertification stages (Liu et al., 2018; Qi et al., 2012). However, these studies only show spatial changes (Duan et al., 2019; Gao et al., 2006), and could not precisely measure the desertification status (aggravation or reversion) along with a time series. Previous studies indicated that desertification processes directly resulted in the depletion of SOC and TN stocks, which declined sharply with the deterioration of desertification (Allington et al., 2010). Accordingly, we supposed that SOC and TN stocks can be used as indicators of desertification. In this study, an integrated method of experimental field data and temporal-spatial changing data was adopted to quantify the desertification process, and this is a new approach for desertification assessment.

This study aims to evaluate the effects of desertification on SOC and TN concentrations and stocks and assess changes of desertification status along with a time series. We selected the southeast edge of the Mu Us sandy land as the study area, used the space-for-time method to classify the desertification degradation gradient into five stages, analyzed variations in SOC and TN concentrations and stocks along the desertification gradient, and quantified total changes of SOC and TN stocks in study area since the Conversion of Cropland to Forest Project has implemented.

\section{Materials and methods}

\section{Study area}

In this investigation, the study area is located on the southeast edge of the Mu Us sandy land, in Yulin City, northern Shaanxi Province, China (Fig. 1). 


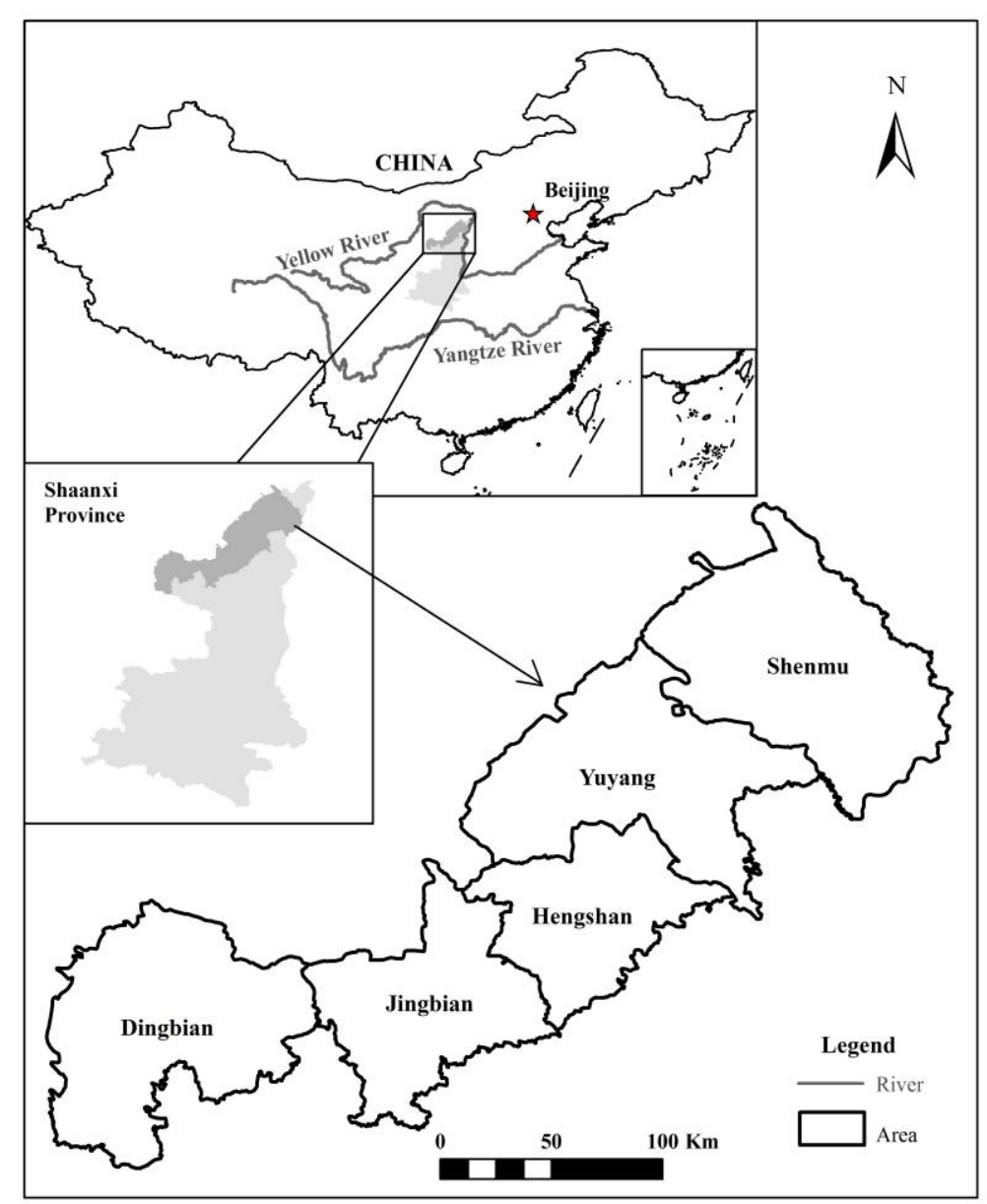

Figure 1. The location of the study area

Geographically, it is located from $36^{\circ} 49^{\prime}$ to $39^{\circ} 27^{\prime}$ E longitude and $107^{\circ} 15^{\prime}$ to $110^{\circ} 54^{\prime} \mathrm{N}$ latitude, and the elevation is 2170 to $3054 \mathrm{~m}$ above sea level, with the relative altitude of 10 to $50 \mathrm{~m}$. It is a temperate continental semi-arid monsoon climate. The mean annual precipitation ranges between 250 and $440 \mathrm{~mm}$, with 60 to $75 \%$ of total yearly precipitation occurring from June to September. The mean annual temperature of this area is about $8^{\circ} \mathrm{C}$. The main soil types are light chestnut soil and chestnut soil in the study area (according to the Chinese Soil Classification System), and according to FAO Soil Classification System, the main soil type is Kastanozem. About $80 \%$ of the study area is sandy land, among which each of fixed sand dunes, semi-fixed sand dunes, and moving sand dunes occupy one third. The dominant vegetation in the moving sand dunes is Chenopodiun album, which is an annual plant. The semi-fixed sand dunes are dominated by shrubs such as Lespedeza davurica and Artemisia ordosica. The fixed sand dunes are dominated by grasses such as Stipa bungeana and Cleistogenes squarrosa.

\section{Sampling and laboratory analysis}

\section{Experimental design and sampling}

In this study, we used the space-for-time method to classify desertification. According to the field survey and the classification of desertification degrees and types 
by Zhu and Wang (Wang et al., 2002), five different desertification stages were selected to represent desertification succession stages. The five stages were the nondesertification stage (ND), potential desertification stage (PD), light desertification stage (LD), moderate desertification stage (MD), and severe desertification stage (SD). Table 1 shows the main characteristics (location, coverage, and dominant species) of each stage. Figure 2 shows some photos of the sampling sites in the study area.

Table 1. The classification of desertification and the main characteristics

\begin{tabular}{|c|c|c|c|c|}
\hline $\begin{array}{c}\text { Desertification } \\
\text { stages }\end{array}$ & Coverage & Main community & $\begin{array}{c}\text { Constructive } \\
\text { species }\end{array}$ & Coordinates \\
\hline $\begin{array}{l}\text { Non- } \\
\text { desertification } \\
\text { (ND) }\end{array}$ & $>70 \%$ & $\begin{array}{c}\text { Stipa bungeana }+ \\
\text { Cleistogenes squarrosa }+ \\
\text { bunch grass }\end{array}$ & Stipa bungeana & 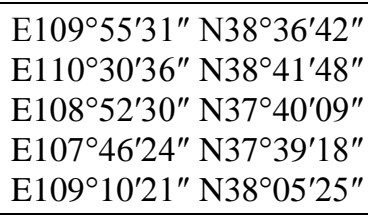 \\
\hline $\begin{array}{c}\text { Potential } \\
\text { desertification } \\
\text { (PD) }\end{array}$ & $50-70 \%$ & $\begin{array}{c}\text { Cleistogenes squarrosa }+ \\
\text { Stipa bungeana }+ \text { Lespedeza } \\
\text { davurica }\end{array}$ & $\begin{array}{l}\text { Cleistogenes } \\
\text { squarrosa }\end{array}$ & 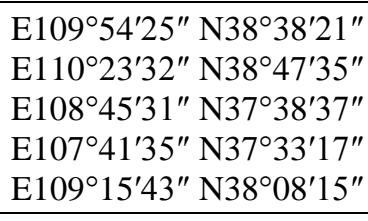 \\
\hline $\begin{array}{l}\text { Light } \\
\text { desertification } \\
\text { (LD) }\end{array}$ & $30-50 \%$ & $\begin{array}{l}\text { Lespedeza davurica }+ \\
\text { Artemisia ordosica }\end{array}$ & $\begin{array}{l}\text { Lespedeza } \\
\text { davurica }\end{array}$ & 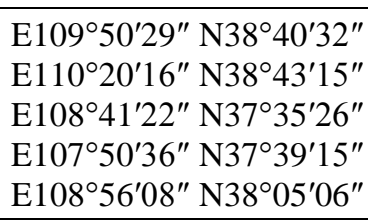 \\
\hline $\begin{array}{l}\text { Moderate } \\
\text { desertification } \\
\text { (MD) }\end{array}$ & $10-30 \%$ & $\begin{array}{l}\text { Artemisia ordosica }+ \\
\text { Cynanchum komarovii }\end{array}$ & $\begin{array}{l}\text { Artemisia } \\
\text { ordosica }\end{array}$ & $\begin{array}{l}\mathrm{E} 109^{\circ} 52^{\prime} 19^{\prime \prime} \mathrm{N} 38^{\circ} 38^{\prime} 20^{\prime \prime} \\
\mathrm{E} 110^{\circ} 20^{\prime} 56^{\prime \prime} \mathrm{N} 38^{\circ} 41^{\prime 2} 24^{\prime \prime} \\
\mathrm{E} 108^{\circ} 38^{\prime} 42^{\prime \prime} \mathrm{N} 37^{\circ} 35^{\prime} 31^{\prime \prime} \\
\mathrm{E} 107^{\circ} 52^{\prime} 20^{\prime \prime} \mathrm{N} 37^{\circ} 43^{\prime} 13^{\prime \prime} \\
\mathrm{E} 108^{\circ} 50^{\prime} 27^{\prime \prime} \mathrm{N} 37^{\circ} 58^{\prime} 22^{\prime \prime}\end{array}$ \\
\hline $\begin{array}{c}\text { Severe } \\
\text { desertification } \\
\text { (SD) }\end{array}$ & $<10 \%$ & Annual herb & $\begin{array}{l}\text { Chenopodiun } \\
\text { album }\end{array}$ & $\begin{array}{l}\text { E109 } 48^{\prime} 22^{\prime \prime} \mathrm{N} 38^{\circ} 32^{\prime} 43^{\prime \prime} \\
\text { E110 } 29^{\prime} 31^{\prime \prime} \mathrm{N} 38^{\circ} 40^{\prime} 48^{\prime \prime} \\
\text { E108 } 37^{\prime} 15^{\prime \prime} \mathrm{N} 37^{\circ} 42^{\prime} 43^{\prime \prime} \\
\text { E108 } 04^{\prime} 17^{\prime \prime} \mathrm{N} 37^{\circ} 48^{\prime} 28^{\prime \prime} \\
\text { E108 } 48^{\circ} 42^{\prime} 11^{\prime \prime} \mathrm{N} 37^{\circ} 52^{\prime} 49^{\prime \prime}\end{array}$ \\
\hline
\end{tabular}

In this research, the fieldwork was conducted at the end of July 2015. We selected five study sites $(10 \mathrm{~m} \times 10 \mathrm{~m})$ for each desertification stage. At each study site, five quadrats were selected to collect samples (Fig. 2). Four quadrants are located in the middle of the line connecting the center point to the center of each side, and one is at the center of all study sites. A total of 125 quadrats were dug for collecting soil samples. Soil samples were taken from six soil depth categories of $0-5 \mathrm{~cm}, 5-10 \mathrm{~cm}, 10-15 \mathrm{~cm}$, 15-20 cm, 20-25 cm, and 25-30 cm. Then the soil samples were put into a sealed plastic bag. Soil bulk density at each site was calculated with a cylinder of $5 \mathrm{~cm}$ diameter and $5 \mathrm{~cm}$ height for each depth interval.

\section{Laboratory analysis}

When the soil samples were brought to the laboratory, they were passed through a $2 \mathrm{~mm}$ sieve to remove roots and litters and air-dried for chemical analysis. SOC was 
measured using the Walkley-Black method, and TN was determined using the Kjeldahl's method (Bao, 2008). Bulk density for each soil layer was calculated using the core method (Bao, 2008).
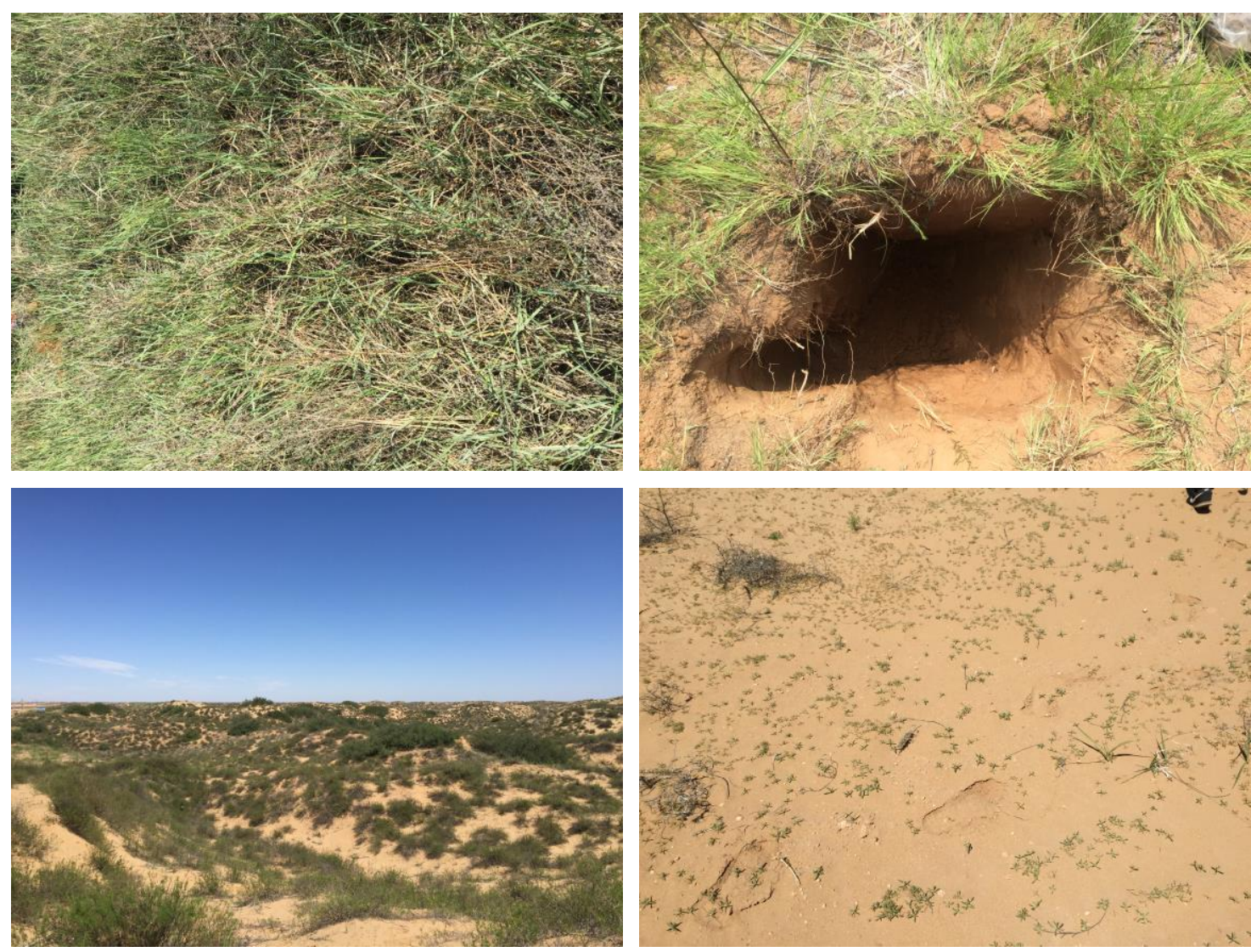

Figure 2. Photos of the sampling sites

Due to the lack of coarse fragments $>2 \mathrm{~mm}$ in the study area, SOC stocks in each soil sample were calculated by Equation 1:

$$
S O C=\sum_{i=1}^{k} B_{i} \times C_{i} \times D_{i} \times 10
$$

where $S O C$ is soil organic carbon stocks $\left(\mathrm{g} \cdot \mathrm{m}^{-2}\right) ; k$ is the number of depth categories $(\mathrm{k}=6) ; B_{i}$ denotes the soil bulk density $\left(\mathrm{g} \cdot \mathrm{m}^{-3}\right) ; C_{i}$ is the soil organic carbon content $\left(\mathrm{g} \cdot \mathrm{kg}^{-1}\right)$, and $D_{i}$ presents soil thickness $(\mathrm{cm})$.

TN stocks in each soil sample were calculated by Equation 2:

$$
T N=\sum_{i=1}^{k} B_{i} \times N_{i} \times D_{i} \times 10
$$

where $T N$ is total nitrogen stocks $\left(\mathrm{g} \cdot \mathrm{m}^{-2}\right)$, and $N_{i}$ is the soil nitrogen concentration $\left(\mathrm{g} \cdot \mathrm{kg}^{-1}\right)$. 


\section{Data analysis approach}

Statistical analyses were performed using IBM SPSS Statistics software. One-way analysis-of-variance (ANOVA) and multiple comparisons were used to examine the differences of the concentrations and stocks of SOC and TN among different desertification stages and different depths (McHugh, 2011).

\section{Results}

\section{Changes in soil bulk density}

Table 2 shows that bulk density varied across soil depths and among different desertification stages. The bulk density in the top layer $(0-5 \mathrm{~cm})$ changed from $1.571 \mathrm{~g} \cdot \mathrm{cm}^{-3}$ in the ND stage to $1.694 \mathrm{~g} \cdot \mathrm{cm}^{-3}$ in the SD stage, but there was no significant difference among five desertification stages $(P>0.05)$. The minimum value of mean bulk density $(0-30 \mathrm{~cm})$ was $1.655 \mathrm{~g} \cdot \mathrm{cm}^{-3}$ in the ND stage, and the maximum value of mean bulk density $(0-30 \mathrm{~cm})$ was $1.671 \mathrm{~g} \cdot \mathrm{cm}^{-3}$ in the SD stage. There was no significant difference among the five desertification stages $(P>0.05)$. Bulk density fluctuated among different soil depths, and the largest values of bulk density were different in every profile. There were no significant differences among the profiles in every desertification stage $(\mathrm{P}>0.05)$.

Table 2. Changes of bulk density in the five stages of desertification

\begin{tabular}{c|c|c|c|c|c|c}
\hline $\begin{array}{c}\text { Bulk density } \\
\left(\mathbf{g} \cdot \mathbf{c m}^{-3}\right)\end{array}$ & $\mathbf{0 - 5} \mathbf{~ c m}$ & $\mathbf{5 - 1 0} \mathbf{~ c m}$ & $\mathbf{1 0 - 1 5} \mathbf{c m}$ & $\mathbf{1 5 - 2 0} \mathbf{~ c m}$ & $\mathbf{2 0 - 2 5} \mathbf{~ c m}$ & $\mathbf{2 5 - 3 0} \mathbf{~ c m}$ \\
\hline ND & $1.571 \pm 0.073$ & $1.627 \pm 0.069$ & $1.667 \pm 0.061$ & $1.696 \pm 0.146$ & $1.674 \pm 0.015$ & $1.694 \pm 0.038$ \\
PD & $1.586 \pm 0.139$ & $1.612 \pm 0.035$ & $1.601 \pm 0.128$ & $1.656 \pm 0.051$ & $1.669 \pm 0.077$ & $1.652 \pm 0.062$ \\
LD & $1.613 \pm 0.030$ & $1.680 \pm 0.058$ & $1.588 \pm 0.176$ & $1.614 \pm 0.079$ & $1.633 \pm 0.064$ & $1.634 \pm 0.066$ \\
MD & $1.639 \pm 0.157$ & $1.673 \pm 0.050$ & $1.622 \pm 0.086$ & $1.609 \pm 0.080$ & $1.621 \pm 0.078$ & $1.635 \pm 0.091$ \\
SD & $1.658 \pm 0.104$ & $1.681 \pm 0.077$ & $1.663 \pm 0.110$ & $1.688 \pm 0.046$ & $1.668 \pm 0.065$ & $1.670 \pm 0.023$ \\
\hline
\end{tabular}

Values are means \pm SD. The values of bulk density were measured in five desertification stages: NDnon-desertification, PD-potential desertification, LD-light desertification, MD-moderate desertification, SD-severe desertification

\section{Changes in SOC and TN concentration}

Figure 3 shows that the SOC and TN concentrations decreased significantly across the desertification stages $(\mathrm{P}<0.05)$. With the process of desertification, SOC concentrations $(0-30 \mathrm{~cm})$ ranged from $2.409 \mathrm{~g} \cdot \mathrm{kg}^{-1}$ in the ND stage to $1.072 \mathrm{~g} \cdot \mathrm{kg}^{-1}$ in the SD stage, whereas TN concentrations $(0-30 \mathrm{~cm})$ ranged from $0.251 \mathrm{~g} \cdot \mathrm{kg}^{-1}$ in the ND stage to $0.113 \mathrm{~g} \cdot \mathrm{kg}^{-1}$ in the SD stage, showing decreases of $55.5 \%$ and $55.1 \%$, respectively. Both SOC and TN concentrations $(0-30 \mathrm{~cm})$ decreased significantly with the severity of desertification $(\mathrm{P}<0.05)$. Compared with the ND stage, SOC concentration in the SD stage decreased by $63.45 \%, 56.74 \%, 51.22 \%, 48.56 \%, 53.84 \%$, and $54.99 \%$ at soil depths of $0-5,5-10,10-15,15-20,20-25$, and $25-30 \mathrm{~cm}$, while the TN concentration decreased by $67.48 \%, 67.40 \%, 46.00 \%, 49.79 \%, 42.61 \%$, and $37.48 \%$, respectively. There also existed significant differences at different layers among different desertification stages $(\mathrm{P}<0.05)$. The largest decreasing ranges of SOC 
and TN concentrations were all observed in the upper layer $(0-5 \mathrm{~cm})$, which showed that desertification had a greater impact on the upper layers than on the deeper layers.

Figure 3 also shows the comparing differences of SOC and TN concentrations between different desertification stages in different soil layers. For SOC concentration, there existed significant differences between PD and SD stage at most soil layers (except $10-15 \mathrm{~cm})(\mathrm{P}<0.05)$. For $\mathrm{TN}$ concentration, significant differences existed between ND and PD stage (except $0-5 \mathrm{~cm}$ and $10-15 \mathrm{~cm})(\mathrm{P}<0.05)$, and in the upper layer $(0-5 \mathrm{~cm})$, a significant difference existed between PD and SD stage $(\mathrm{P}<0.05)$. The decreasing results also indicate that the decline ranges of SOC and TN concentrations differed among two desertification stages. The highest decreasing ranges of SOC concentration was existed in the PD to SD stage, with decreases of $24.9 \%$ throughout $0-30 \mathrm{~cm}$ layer and $37.42 \%$ in the top layer $(0-5 \mathrm{~cm})$. Influenced by the top layer, the greatest decreasing ranges of $\mathrm{TN}$ concentration also existed in the PD to SD stage, which were $18.8 \%$ in $0-30 \mathrm{~cm}$ layer and $43.13 \%$ in $0-5 \mathrm{~cm}$ layer. These results show that SOC and TN concentrations in different desertification stages were significantly affected by desertification, especially in the early stages.
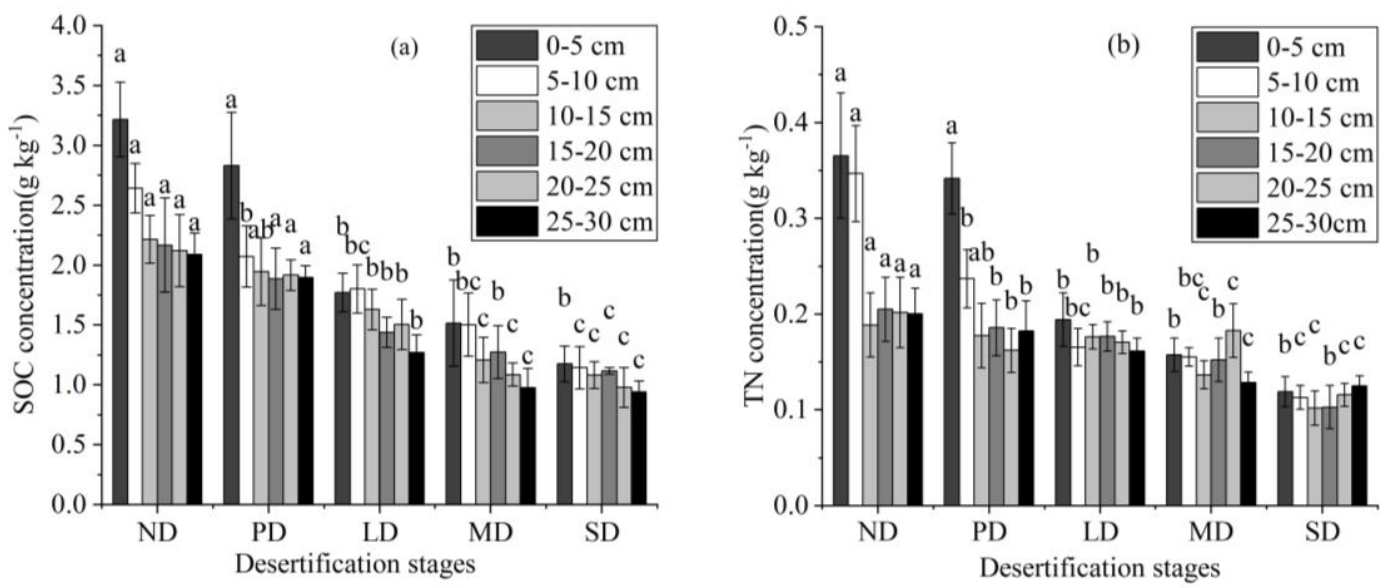

Figure 3. Changes in the SOC and TN concentrations in five desertification stages. (a) SOC concentration; (b) TN concentration. SOC and TN concentrations were measured in five desertification stages: ND-non-desertification, PD-potential desertification, LD-light desertification, $M D$-moderate desertification, $S D$-severe desertification. Error bars indicate the standard deviation. Variations significant at the 0.05 level is indicated by different lowercase letters $(P<0.05)$

\section{Changes in SOC and TN stocks}

According to Figure 4, with the desertification development, SOC and TN stocks decreased significantly $(\mathrm{P}<0.05)$. SOC stocks in the top soil layer $(0-5 \mathrm{~cm})$ ranged from $252.73 \mathrm{~g} \cdot \mathrm{m}^{-2}$ in the ND stage to $97.84 \mathrm{~g} \cdot \mathrm{m}^{-2}$ in the SD stage, and TN stocks in this layer declined from $28.86 \mathrm{~g} \cdot \mathrm{m}^{-2}$ in the ND stage to $9.90 \mathrm{~g} \cdot \mathrm{m}^{-2}$ in the SD stage, decreasing by $61.3 \%$ and $65.7 \%$, respectively $(\mathrm{P}<0.05)$. The SOC and TN stocks also decreased from the top soil layer to the deeper layer, but the decreasing magnitudes were different in different desertification stages. From $10-15 \mathrm{~cm}$ to deeper soil layers, there was no significant difference $(\mathrm{P}>0.05)$ in both SOC and TN stocks. 
Figure 4 also shows the comparing differences of SOC and TN stocks between different desertification stages in different soil layers and at different soil depths. Figure $4 a$ shows that, for SOC stocks, there existed significant differences between PD stage and the LD stage $(\mathrm{P}<0.05)$ in most of the soil layers. Figure $4 b$ shows that, for TN stocks, significant differences were observed mainly between PD stage and LD stage $(\mathrm{P}<0.05)$ in $0-5 \mathrm{~cm}$ and $5-10 \mathrm{~cm}$ depths $(\mathrm{P}<0.05)$. Figure $4 c$ and $d$ show that $\mathrm{SOC}$ and TN stocks decreased significantly at different soil depths $(\mathrm{P}<0.05)$, and there existed significant differences between every two desertification stages $(\mathrm{P}<0.05)$. These results show that desertification strongly influenced SOC and TN stocks in the study area.
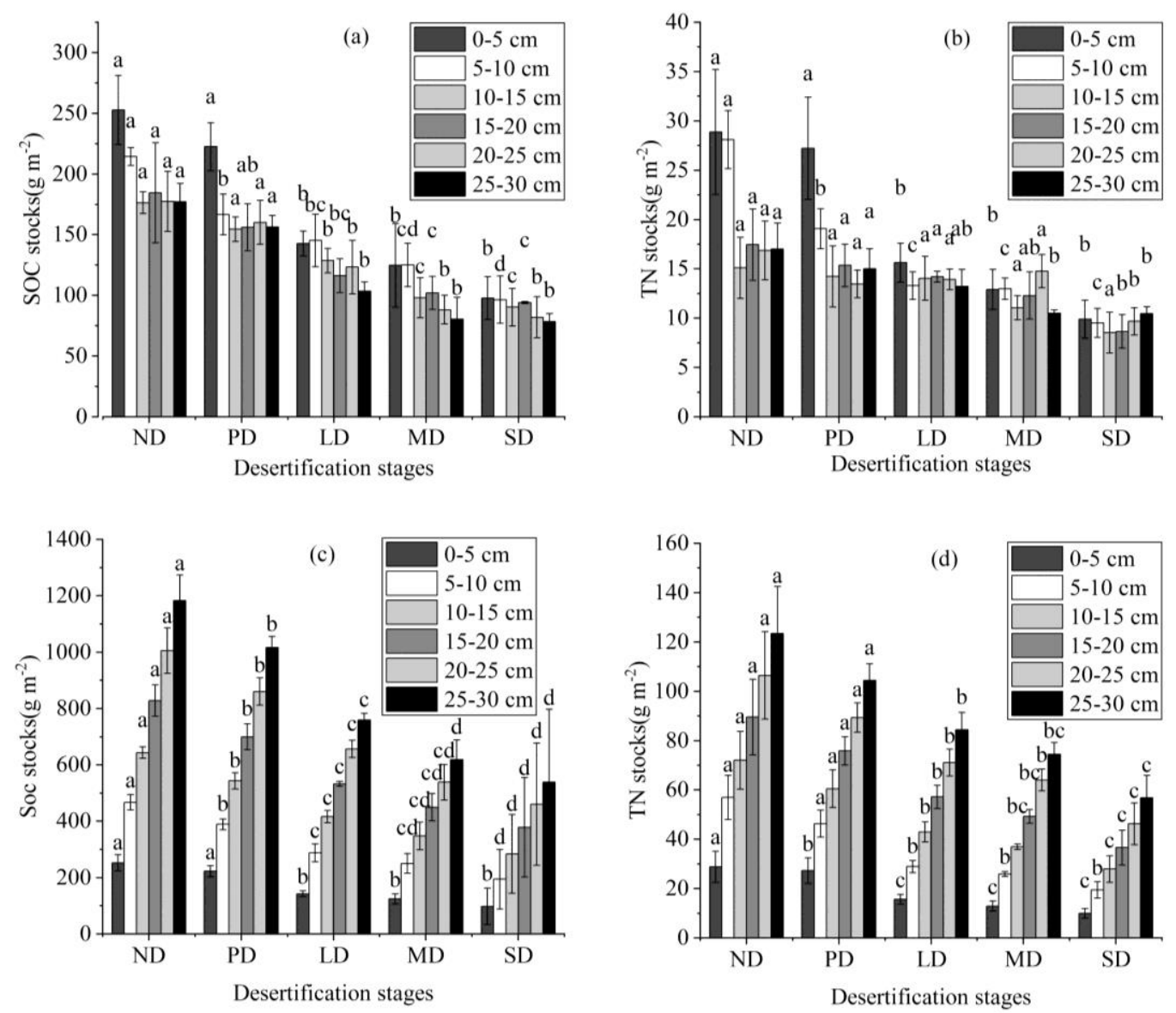

Figure 4. Changes in the SOC and TN stocks in five desertification stages. (a) SOC stocks in different soil layers; (b) TN stocks in different soil layers; (c) SOC stocks at different soil depths; (d) TN stocks at different soil depths. SOC and TN stocks were measured in five desertification stages: ND-non-desertification, PD-potential desertification, LD-light desertification, $M D$-moderate desertification, SD-severe desertification. Error bars indicate the standard deviation. Variations significant at the 0.05 level are indicated by different lowercase letters $(P<0.05)$

Figure 5 shows that, with the process of desertification, SOC, and TN stocks in 0 $30 \mathrm{~cm}$ depth reduced significantly $(\mathrm{P}<0.05)$. SOC stocks $(0-30 \mathrm{~cm})$ decreased from $1182.73 \mathrm{~g} \cdot \mathrm{m}^{-2}$ in the ND stage to $539.21 \mathrm{~g} \cdot \mathrm{m}^{-2}$ in the SD stage, and TN stocks $(0-30 \mathrm{~cm})$ decreased from $123.42 \mathrm{~g} \cdot \mathrm{m}^{-2}$ in the ND stage to $56.75 \mathrm{~g} \cdot \mathrm{m}^{-2}$ in the SD stage, accounting for decreases of $54.4 \%$ and $54.0 \%$, respectively $(\mathrm{P}<0.05)$. The total losses of SOC and 
TN stocks in the SD stage compared to the ND stage were $653.52 \mathrm{~g} \cdot \mathrm{m}^{-2}$ and $66.67 \mathrm{~g} \cdot \mathrm{m}^{-2}$, respectively. The data also showed that the losses of SOD and TN stocks from the PD to LD stages were the most comparable to the losses between other contiguous stages.
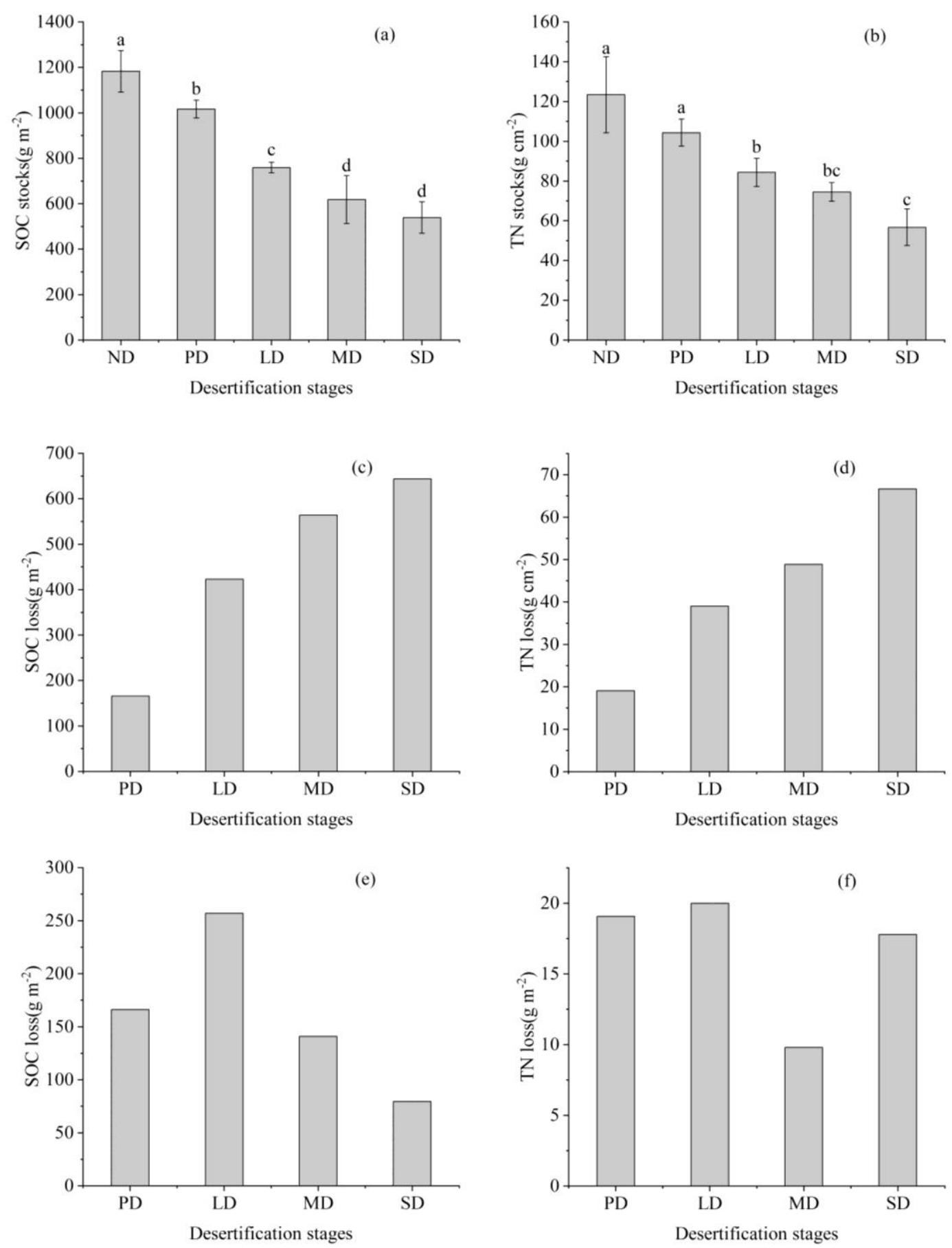

Figure 5. Changes in the SOC and TN stocks in 0-30 depth in five desertification stages. (a) SOC stocks in 0-30 depth; (b) TN stocks in 0-30 depth; (c) SOC loss compared to ND; (d) TN loss compared to ND; (e) SOC loss compared to contiguous stages; $(f)$ TN loss compared to contiguous stages. SOC and TN stocks and losses were measured in five desertification stages: ND-Non-desertification, PD-potential desertification, LD-light desertification, $M D$-moderate desertification, $S D$-severe desertification. Error bars indicate the standard deviation.

Variations significant at the 0.05 level are indicated by different lowercase letters $(P<0.05)$ 


\section{Total changes in SOC and TN stocks from 2003 to 2015}

According to Table 3, we monitored the area changes of different desertification stages from 2003 to 2015. The area changes between different desertification stages could be observed, but the reversal or aggravation of desertification could not be precisely assessed. Calculation of the total changes of SOC and TN stocks from 2003 to 2015 show that the SOC and TN stocks increased by $4.25 \times 10^{8} \mathrm{~kg}$ and $0.71 \times 10^{8} \mathrm{~kg}$, respectively. Thus, the authors conclude that the same amounts of SOC and TN were accumulated during this period. Therefore, we could conclude that the desertification was a reversal from 2003 to 2015 .

Table 3. The total changes of SOC and TN stocks $(0-30 \mathrm{~cm})$ in the study area from 2003 to 2015

\begin{tabular}{c|c|c|c|c|c|c|c|c|c}
\hline \multirow{2}{*}{\multicolumn{2}{c|}{ Type }} & \multicolumn{7}{|c|}{ Area 2015 $\left(\mathbf{k m}^{2}\right)$} & \multicolumn{2}{c}{$\begin{array}{c}\text { Stocks 2003 } \\
\left(\times 10^{8} \mathbf{k g}\right)\end{array}$} \\
\cline { 3 - 10 } \multicolumn{2}{c}{} & ND & PD & LD & MD & SD & $\begin{array}{c}\text { Total } \\
\text { Area }\end{array}$ & SOC & TN \\
\hline & ND & 62.81 & 65.31 & 12.80 & 9.83 & 3.43 & 154.18 & 1.82 & 0.19 \\
& PD & 86.89 & 2554.57 & 735.65 & 1475.73 & 290.28 & 5143.11 & 52.29 & 5.37 \\
$\begin{array}{c}\text { Area } 2003 \\
\left(\mathrm{~km}^{2}\right)\end{array}$ & LD & 12.07 & 1644.75 & 1217.18 & 2579.24 & 686.70 & 6139.95 & 46.64 & 5.18 \\
& MD & 12.93 & 1380.6 & 2029.89 & 5255.4 & 1707.69 & 10386.50 & 64.27 & 7.74 \\
& SD & 6.00 & 367.00 & 756.70 & 4834.03 & 3241.40 & 9205.14 & 49.64 & 5.22 \\
& Total area & 180.7 & 6012.23 & 4752.23 & 14154.23 & 5929.5 & 31028.87 & 214.66 & 23.7 \\
\hline $\begin{array}{c}\text { Stocks 2015 } \\
\left(\times 10^{8} \mathrm{~kg}\right)\end{array}$ & SOC & 2.14 & 61.12 & 36.1 & 87.58 & 31.97 & 218.91 & $\mathbf{4 . 2 5}$ & \\
\hline
\end{tabular}

ND-non-desertification, PD-potential desertification, LD-light desertification, MD-moderate desertification, SD-severe desertification

\section{Discussion}

Desertification is a global disaster and has strongly affected many places and large populations around the world. Many studies have demonstrated that desertification would induce dramatic changes in the physical properties and nutrients of soil (Hu et al., 2017; Qiu et al., 2012). The results of our study demonstrate that the soil bulk density changed little in the upper layer $(0-5 \mathrm{~cm})$ with desertification, there was no significant difference among different desertification stages $(\mathrm{P}>0.05)$.

Our results demonstrate that desertification had a remarkable effect on SOC and TN concentrations in the southeast edge of the Mu Us sandy land. The effects were observed not only in different desertification stages but also at different soil depths. SOC and TN concentrations decreased significantly with the process of desertification, which is similar to the outcome of Zhou et al. (2008). This could be mainly due to the decrease in vegetation cover and wind erosion (Albaladejo et al., 1998). Vegetation is the primary source of soil nutrients, and aeolian erosion is considered the trigger of desertification because it could remove fine soil particles rich in nutrients, and then leads to the reduction of SOC and TN concentrations. The results also indicate that the declining rates of SOC and TN concentrations were different between two contiguous stages. From the PD stage to the LD stage, the decreasing ranges of both SOC concentration and TN concentration were larger than those in other contiguous stages. 
This situation supports the results of Zhao et al. (2009) and Tang et al. (2015), which also demonstrated that SOC and TN decreased more sharply in early desertification stages.

In contrast, in a study on the impacts of desertification on alpine-cold grassland, $\mathrm{Hu}$ et al. (2017) reported that, with the progression of desertification, the rate of SOC loss accelerated, which is not consistent with our results (Hu et al., 2017). This may be because of the different climate between alpine-cold and semiarid areas. The results of our study also show that SOC and TN concentrations decreased with deeper soil layers, but they declined faster in the upper layer, which indicated that desertification has more significant effects on the top soil. Our results are consistent with the findings of Zhu et al. (1994), in which desertification was found to firstly affect the top soil.

This study shows that, with the aggravation of desertification, both SOC and TN stocks decreased significantly, with the highest SOC and TN stocks in the ND stage and lowest of them in the SD stage. Compared with the ND stage, the losses of SOC and TN stocks were the largest in the SD stage. The losses of SOC and TN stocks would result in the deterioration of land productivity, which will further lead to land degradation and increased desertification; it increases the release of $\mathrm{CO}_{2}, \mathrm{NO}_{\mathrm{x}}$, and other greenhouse gases to the atmosphere, which could accelerate climate change. Besides, Figure 5 shows that desertification effects on SOC and TN stocks were most severe in the LD stage, which confirmed the results of SOC and TN concentrations. This is also consistent with the viewpoint of Wang et al. (2002) and Zhou et al. (2008), their studies reported that the impact of desertification on $\mathrm{C}$ and $\mathrm{N}$ stocks were significantly different in five desertification stages. In the further control of desertification, the stages with the most severe changes should be given more attention because they are vital to the restoration of desertification.

Human factors, such as over-cultivation and overgrazing, are believed to be critical factors promoting desertification ( $\mathrm{Li}$ et al., 2017). The Mu Us Sandy Land, which is located in the agropastoral ecotone of China, is extremely sensitive and fragile and has poor self-restoration ability to external disturbance (Liu et al., 2012). In the 20th century, this area suffered from extensive grazing and cultivating, and experienced the threat of sandy desertification (Li et al., 2017). Fortunately, since 1999; the Conversion of Cropland to Forest Project was implemented, and inappropriate land-use activities were forbidden (Li et al., 2017). Recently, many studies based on statistic data or RS and GIS reported that the Conversion of Cropland to Forest Project had practical impacts on combating land desertification and promoting vegetation restoration in this area (Liang et al., 2016; Wang, 2018; Zhang et al., 2008). These studies show that desertification reversion is associated with the restoration of soil nutrient levels. However, previous research only analyzed area changes of different land use or different desertification stages. Accordingly, this study calculated the total changes of SOC and TN stocks to evaluate the changes in soil nutrient levels for further assessing whether the desertification has reversed or not since the implementation of the Conversion of Cropland to Forest Project. Our results showed that $4.25 \times 10^{8} \mathrm{~kg}$ SOC and $0.71 \times 10^{8} \mathrm{~kg}$ TN were accumulated since 2003, which confirmed the findings of previous studies and indicates the active influence of the Conversion of Cropland to Forest Project on the restoration of the ecosystem. Indeed, this study not only presents a new method for the quantitative assessment of desertification but also has meaning for the calculation of the potential of soil carbon and nitrogen fixation in the reversal of desertification. At the same time, the results support the view that returning cultivated 
land to grassland and long-term livestock removal were effective in restoring desertification in this site and also provide encouragement for managers to re-establish the ecosystem of damaged grasslands.

\section{Conclusions}

In this investigation, results show that desertification affected SOC and TN concentrations significantly, especially in the top soil, and deeper soil depths. Desertification also resulted in remarkable losses of SOC and TN stocks $(0-30 \mathrm{~cm})$, with losses of $643.52 \mathrm{~g} \cdot \mathrm{m}^{-2}$ and $66.67 \mathrm{~g} \cdot \mathrm{m}^{-2}$, respectively. Besides, the losses of SOC and TN stocks from PD stages to LD stages were the largest between two contiguous stages, which means that the early stages of desertification are crucial periods for the restoration of desertification. More attention should be given to these stages of combating desertification. An integrated analysis of field experiment data and temporalspatial changing data was used to calculate the total changes of SOC and TN stocks, the results show that, from 2003 to 2015 , total SOC and TN stocks increased by $4.25 \times 10^{8} \mathrm{~kg}$ and $0.71 \times 10^{8} \mathrm{~kg}$, respectively. The results not only indicate that the desertification reversed during this period, but also indicate that this method could provide a new quantitative method to assess the desertification process. The results of this study also support the effectiveness of the Conversion of Cropland to Forest Project in grassland ecosystems. For the future study, a more accurate method needs to be furtherly explored so that the fieldwork and experiment data can be in better accordance with the temporal-spatial analysis data.

Acknowledgements. This work was supported by the National Natural Science Foundation of China (41501571), Shaanxi Provincial Natural Science Foundation of China (2015JQ4110); China Scholarship Council Foundation (201808615052).

\section{REFERENCES}

[1] Agren, G. I., Bosatta, E. (1987): Theoretical-analysis of the long-term dynamics of carbon and nitrogen in soils. - Ecology 68: 1181-1189.

[2] Albaladejo, J., Martinez-Mena, M., Roldan, A., Castillo, V. (1998): Soil degradation and desertification induced by vegetation removal in a semiarid environment. - Soil Use Manage 14: 1-5.

[3] Alireza, R. A. H., Shahla, M. (2017): Organic and inorganic carbon storage in soils along an arid to dry sub-humid climosequence in northwest of Iran. - Catena 153: 66-74.

[4] Allington, G. R. H., Valone, T. J. (2010): Reversal of desertification: the role of physical and chemical soil properties. - Journal of Arid Environment 74: 973-977.

[5] Aweke, M., Gelaw, B. R. S., Lal, R. (2015): Organic carbon and nitrogen associated with soil aggregates and particle sizes under different land use in Trigay, Northern Ethiopia. Land Degradation \& Development 26: 690-700.

[6] Bao, S. D. (2008): Agricultural and chemical analysis methods of soils. - China Agriculture Press, Beijing.

[7] Batjes, N. H. (1996): Total carbon and nitrogen in the soils of the world. - European Journal of Soil Science 47: 151-163.

[8] Binns, T. (2000): World atlas of desertification., 2nd edition. - Applied Geography 20: 83-84. 
[9] Bouwman, A. F. (1990): Soils and the Greenhouse Effect - Introduction. - In: Bouwman, A. F. (ed.) Soils and the Greenhouse Effect. Wiley, Chichester, pp. 25-32.

[10] Carr, S., Mpande, R. (1996): Does the definition of the issue matter? NGO influence and the International Convention to Combat Desertification in Africa. - The Journal of Commonwealth \& Comparative Politics 34: 143-166.

[11] Deng, L., Zhu, G. Y., Tang, Z. S., Shangguan, Z. P. (2016): Global patterns of the effects of land-use changes on soil carbon stocks. - Global Ecology and Conservation 5: 127138.

[12] Dessie, A. B. R., Hans, S., Christoph, R., Abrham, A., Birru, Y., Douglas, L. G. (2017): Deforestation and land use strongly effect soil organic carbon and nitrogen stock in Northwest Ethiopia. - Catena 153: 89-99.

[13] Detwiler, R. P. (1986): Land-use change and the global carbon-cycle - the role of tropical soils. - Biogeochemistry 2: 67-93.

[14] Duan, H. C., Wang, T., Xue, X., Yan, C. Z. (2019): Dynamic monitoring of aeolian desertification based on multiple indicators in Horqin Sandy Land, China. - Science of Total Environment 650: 2374-2388.

[15] Emanuel, W. R., Killough, G. G., Post, W. M., Shugart, H. H. (1984): Modeling terrestrial ecosystems in the global carbon-cycle with shifts in carbon storage capacity by land-use change. - Ecology 65: 970-983.

[16] Gao, H. J., Jiang, Q. G. (2006): Research of desert and sandy desertification land partition in North China based on remote sensing technology. - Remote Sensing of the Environment: 15th National Symposium on Remote Sensing of China 6200, Guiyan City, China.

[17] Hu, Y. F., Jiang, S. L., Yuan, S., Deng, L. J., Xiao, H. H., Shu, X. Y., Chen, G. D., Xia, J. G. (2017): Changes in soil organic carbon and its active fractions in different desertification stages of alpine-cold grassland in the eastern Qinghai-Tibet Plateau. Environmental Earth Science 76: 348.

[18] Huang, D., Wang, K., Wu, W. L. (2007): Dynamics of soil physical and chemical properties and vegetation succession characteristics during grassland desertification under sheep grazing in an agro-pastoral transition zone in northern China. - Journal of Arid Environment 70: 120-136.

[19] Jenkinson, D. S., Rayner, J. H. (1977): Turnover of soil organic-matter in some of Rothamsted classical experiments. - Soil Science 123: 298-305.

[20] Kelly, R. H., Burke, I. C., Lauenroth, W. K. (1996): Soil organic matter and nutrient availability responses to reduced plant inputs in shortgrass steppe. - Ecology 77: 25162527.

[21] Kirschbaum, M. U. F. (2000): Will changes in soil organic carbon act as a positive or negative feedback on global warming? - Biogeochemistry 48: 21-51.

[22] Lamchin, M., Lee, J. Y., Lee, W. K., Lee, E. J., Kim, M., Lim, C. H., Choi, H. A., Kim, S. R. (2016): Assessment of land cover change and desertification using remote sensing technology in a local region of Mongolia. - Advances in Space Research 57: 64-77.

[23] Li, S., Wang, T., Yan, C. Z. (2017): Assessing the role of policies on land-use/cover change from 1965 to 2015 in the Mu Us sandy land, northern China. - Sustainability 9: 1164.

[24] Liang, P., Yang, X. P. (2016): Landscape spatial patterns in the Maowusu (Mu Us) Sandy Land, northern China and their impact factors. - Catena 145: 321-333.

[25] Liu, Q. F., Zhao, Y. Y., Zhang, X. F., Buyantuev, A., Niu, J. M., Wang, X. J. (2018): Spatiotemporal patterns of desertification dynamics and desertification effects on ecosystem services in the Mu Us Desert in China. - Sustainability 10: 589.

[26] McHugh, M. L. (2011): Multiple comparison analysis testing in ANOVA. - Biochemia Medica 21: 203-209. 
[27] Mehari, A., Tesfaye, F. B., Ruiz, R. P., Valentín, P., Andrés, B. O. (2016): Impact of changes in land use, species and elevation on soil organic carbon and total nitrogen in Ethiopian Central Highlands. - Geoderma 261: 70-79.

[28] Post, W. M., Emanuel, W. R., Zinke, P. J., Stangenberger, A. G. (1982): Soil carbon pools and world life zones. - Nature 298: 156-159.

[29] Qi, Y. B., Chang, Q. R., Jia, K. L., Liu, M. Y., Liu, J., Chen, T. (2012): Temporal-spatial variability of desertification in an agro-pastoral transitional zone of northern Shaanxi Province, China. - Catena 88: 37-45.

[30] Qiu, L. P., Wei, X. R., Zhang, X. C., Cheng, J. M., Gale, W., Guo, C., Long, T. (2012): Soil organic carbon losses due to land use change in a semiarid grassland. - Plant Soil 355: 299-309.

[31] Russell, A. E., Laird, D. A., Parkin, T. B., Mallarino, A. P. (2005): Impact of nitrogen fertilization and cropping system on carbon sequestration in Midwestern Mollisols. - Soil Science Society of America Journal 69: 413-422.

[32] Spycher, G., Sollins, P., Rose, S. (1983): Carbon and nitrogen in the lightfraction of a forest soil - vertical-distribution and seasonal patterns. - Soil Science 135: 79-87.

[33] Tang, Z. S., An, H., Shangguan, Z. P. (2015): The impact of desertification on carbon and nitrogen storage in the desert steppe ecosystem. - Ecological Engineering 84: 92-99.

[34] Twongyirwe, R., Sheil, D., Majaliwa, J. G. M., Ebanyat, P., Tenywa, M. M., Van Heist, M., Kumar, L. (2013): Variability of soil organic carbon stocks under different land uses: a study in an afro-montane landscape in southwestern Uganda. - Geoderma 193: 282289.

[35] UNCCD (1994): United Nations Convention to Combat Desertification in Those Countries Experiencing Serious Drought and/or Desertification, Particularly in Africa. UNCCD, Paris.

[36] Van Minnen, J. G., Goldewijk, K. K., Stehfest, E., Eickhout, B., Van Drecht, G., Leemans, R. (2009): The importance of three centuries of land-use change for the global and regional terrestrial carbon cycle. - Climatic Change 97: 123-144.

[37] Wang, L., Jia, D., Shi, H. S., Lin, Q. Z., Ge, M. L., Xu, Y. M. (2006): Possibilities of multi-spectral data for the assessment of soil nitrogen content. - 2006 IEEE International Symposium on Geoscience and Remote Sensing, Denver, CO.

[38] Wang, T. (2018): Impacts of the Grain for Green Project on soil erosion: a case study in the Wuding River and Luohe River basins in the Shaanxi Province of China. - Applied Ecology and Environmental Research 16: 4165-4181.

[39] Wang, T., Zhu, Z., Wu, W. (2002): Sandy desertification in the north of China. - Science in China Series D 45: 23-34.

[40] Zhang, Y. Z., Chen, Z. Y., Zhu, B. Q., Luo, X. Y., Guan, Y. N., Guo, S., Nie, Y. P. (2008): Land desertification monitoring and assessment in Yulin of Northwest China using remote sensing and geographic information systems (GIS). - Environmental Monitoring Assessment 147: 327-337.

[41] Zhang, Z. H., Huisingh, D. (2018): Combating desertification in China: monitoring, control, management and revegetation. - Journal of Cleaner Production 182: 765-775.

[42] Zhao, H. L., He, Y. H., Zhou, R. L., Su, Y. Z., Li, Y. Q., Drake, S. (2009): Effects of desertification on soil organic $\mathrm{C}$ and $\mathrm{N}$ content in sandy farmland and grassland of Inner Mongolia. - Catena 77: 187-191.

[43] Zhou, R. L., Li, Y. Q., Zhao, H. L., Drake, S. (2008): Desertification effects on C and N content of sandy soils under grassland in Horqin, northern China. - Geoderma 145: 370375.

[44] Zhu, Z. D., Chen, G. T. (1994): Sandy desertification in China. - Science Press, Beijing. 